\title{
THE BIOLOGY OF NINE TERMITE SPECIES (ISOPTERA: TERMITIDAE) \\ FROM THE CERRADO OF CENTRAL BRAZIL
}

\author{
By Helen R. Coles de Negret ${ }^{1}$ and Kent H. Redford ${ }^{2}$
}

\section{INTRODUCTION}

The Neotropical region is second to the Ethiopian in numbers of described termite species (Araujo 1970). However, little is known of their biology. The literature on Brazilian termites is largely restricted to isolated taxonomic descriptions of species from the Amazon Basin and southern states of Brazil (Araujo 1961, 1969, 1977 and Fontes 1979). Exceptions to this include information relating termite species and their distribution to vegetation types in Mato Grosso State (Mathews 1977), the effect of deforestation on termites in the Amazon (Bandeira 1979) and data on the ecology and defense of termites in the cerrado vegetation of the Distrito Federal (Coles 1980).

The present study was done in conjunction with a study on mammalian termite predators, in particular the giant anteater, Myrmecophaga tridactyla (Coles 1980 and Redford in prep.). Six aspects of termite biology of importance in defense by termites against mammalian predators were studied for nine of the most common mound-building termite species in the Distrito Federal, Brazil. Reported here are individual weights, morphology of soldier castes, worker-soldier ratios, mound sizes and forms, mound hardnesses and nest materials, distributions and abundances of nests and feeding habits for these nine species.

All species studied were from the family Termitidae (see Fig. 1 for comparison of soldier heads), subfamily Apicotermitinae, Grigiotermes metoecus (Matthews); subfamily Nasutitermitinae, Armitermes

${ }^{1}$ Laboratoria de Zoologia e Ecologia Animal, Universidade de Brasilia, Brasilia D. F. 80910, Brazil.

${ }^{2}$ Museum of Comparative Zoology, Harvard University, Cambridge, MA 02138; and Department of Zoological Research, National Zoological Park, Smithsonian Institution, Washington, D.C. 20008.

Manuscript received by the editor March 3, 1982. 
euamignathus (Silvestri), Cornitermes cumulans (Kollar), Cortaritermes silvestri (Holmgren), Nasutitermes sp., Procornitermes araujoi (Emerson), Syntermes dirus (Burmeister), Velocitermes paucipilis (Mathews); subfamily Termitinae, Orthognathotermes gibberorum (Mathews).

\section{MethodS AND ResUlts}

This study was conducted primarily in the Distrito Federal, Brazil (15 47'S 47 56' W) with supporting work done in Emas National Park, Goias State (18 19'S $\left.5245^{\prime} \mathrm{W}\right)$. Both areas are located within the cerrado sensu latu vegetation type. Cerrado (sensu latu) is a semi-deciduous xeromorphic savanna vegetation found in the intermediate rainfall $(750-2000 \mathrm{~mm} / \mathrm{yr})$ area of Brazil. It is characterized by woody plants with thick bark and coreaceous leaves and a seasonal ground layer of grasses and herbs. Although geographically and floristically the cerrado vegetation zone is very uniform, physionomically it shows considerable variation (Eiten 1972). The types of cerrado sensu latu which were examined in this study are campo limpo (grassland), campo sujo (grassland with shrubs), cerrado sensu strictu (woodland) and cerradão (dense, tall cerrado). Within the cerrado zone, gallery forest vegetation is found on the wet, more fertile soils along river courses; however this was excluded from the present study as it supports a termite fauna which differs greatly from that of the other vegetation types (Coles 1980).

\section{The Termites}

\section{A. Comparative Morphology}

Figure 1 depicts soldiers of the eight species of termites examined in this study, with a worker head of the soldierless species Grigiotermes provided for comparison, while Tables 1 and 2 provide information on the fresh weights and total body lengths. Table 2 also provides measurements of mandible length, nasus length, head length, head width and head depth for the soldiers (position of measurements depicted in Figure 2).

As can be seen from these data, the termite species in this study can be placed along a spectrum based on soldier and head shape. The two ends of this spectrum are "well-developed nasus/vestigial mandibles' (such as Nasutitermes) and 'no nasus/very well-devel- 

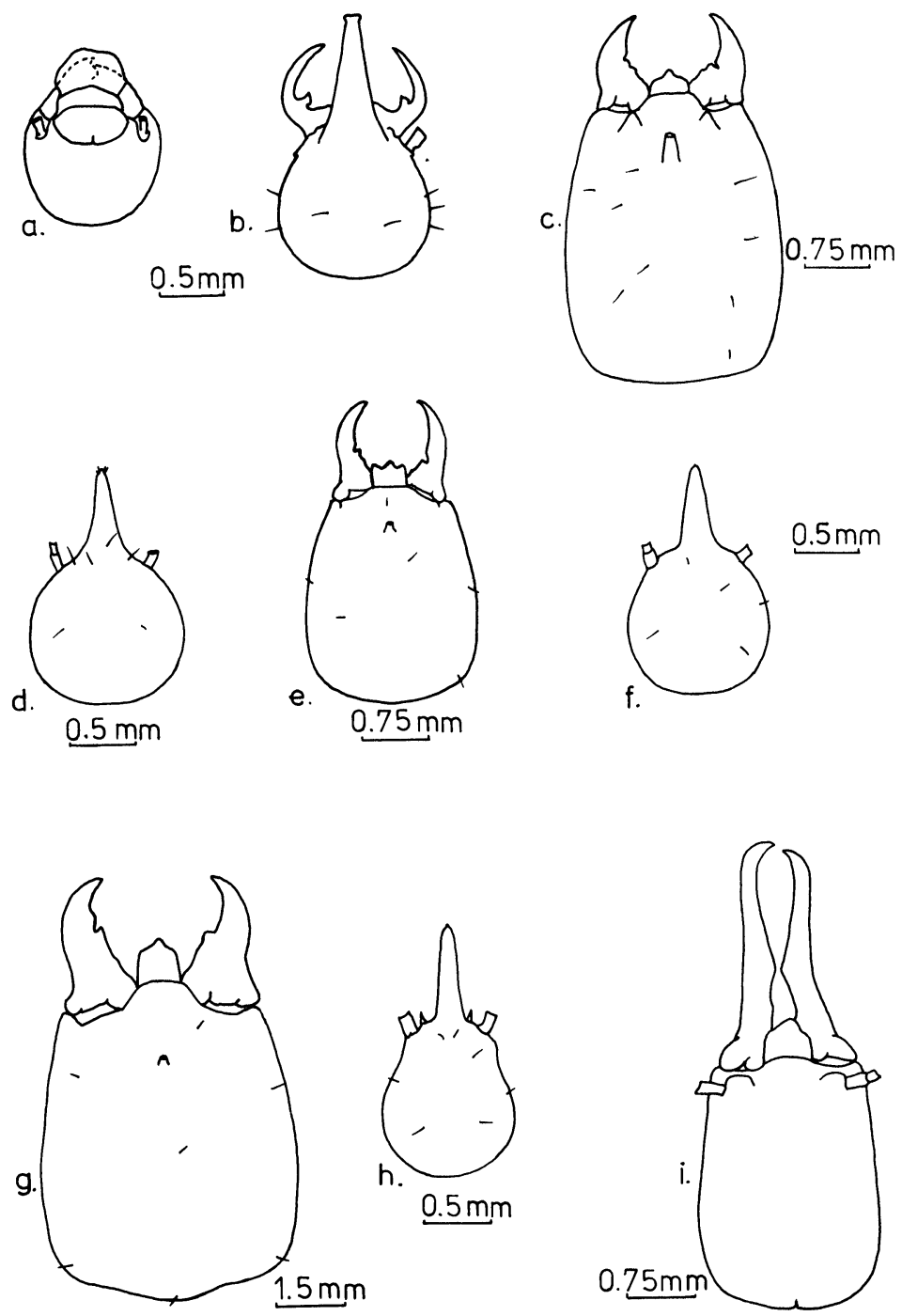

Figure 1. Soldier heads of eight of the species of termites studied; Grigiotermes metoecus worker included for comparison: a, Grigiotermes metoecus; b, Armitermes euamignathus; c, Cornitermes cumulans; d, Cortaritermes silvestri; e, Procornitermes araujoi; f, Nasutitermes sp.; g, Syntermes dirus; h, Velocitermes paucipilis; i, Orthognathotermes gibberorum. 
loped mandibles' (Orthognathotermes). Intermediate positions are occupied by forms with 'slight nasus development/well-developed mandibles' (such as Cornitermes) and 'well-developed nasus/welldeveloped mandibles' (Armitermes). Grigiotermes, with no soldier caste, cannot be placed on this spectrum.

These data also show that soldiers with very well- to welldeveloped mandibles and poorly developed nasi are both heavier and longer than soldiers with vestigial mandibles and well-developed nasi, Armitermes once again occupying an intermediate position.

Complete taxonomic descriptions for Grigiotermes metoecus, Armitermes euamignathus, Cortaritermes silvestri, Velocitermes paucipilis, and Orthognathotermes gibberorum can be found in Mathews (1977). Procornitermes araujoi is fully described in Emerson (1952). Samples of Cornitermes cumulans collected during the study in Brasilia were identified following Emerson (1952). Although the general head and mandible forms were consistent with the published description, head length and width measurements were much lower than those previously described for this species. However, Emerson indicated that there is considerable variation in mean measurements between colonies from different localities. The samples from Brasilia were compared with various other species in the Museu Zoologia de Universidade de São Paulo (MZSP). The most closely related species was $C$. villosus which was clearly different in that it had a greater number of setae and differently shaped mandibles. As a result of this divergence the best classification appears to be $C$. cumulans. Specimens from Brasilia have been deposited in the MZSP and the Museum of Comparative Zoology, Harvard University.

Samples of Nasutitermes sp. collected from the Distrito Federal were compared extensively with material in the MZSP but differed from all species examined. $N$. coxipoensis most resembled the Nasutitermes we studied but differed in being smaller and in having a more oval shaped head. Further studies on these two forms are necessary to determine whether these differences are sufficient to warrant calling it a new species.

\section{B. Weights}

Fresh weights were measured on a Mettler balance. Fifty workers and fifty soldiers from each of three different nests were weighed, except for Syntermes for which only fifteen individuals of each caste 
from the three nests were weighed and Nasutitermes for which five nests were sampled. The results are presented in Table 1 and are ordered from heaviest soldiers to lightest soldiers. Syntermes dirus has workers and soldiers much heavier than the next heaviest species, Cornitermes. The termite species with soldiers possessing strong or long mandibles are heavier than those termites whose soldiers have vestigial mandibles, and well developed nasi. These latter soldiers are also lighter than their workers, a relationship reversed in the other termite species.

Table 1. Individual wet weights of termites (measurements expressed in micrograms; mean with standard deviation in parentheses).

\begin{tabular}{lcc}
\hline Species & Workers & Soldiers \\
\hline Syntermes dirus & $42.75 \mathrm{a}$ & 117.3 \\
& $(2.34)$ & $(11.1)$ \\
Cornitermes cumulans & 9.30 & 19.83 \\
& $(0.36)$ & $(1.07)$ \\
Orthognathotermes gibberorum & 6.91 & $19.09 \mathrm{~b}$ \\
& $(0.75)$ & $(0.69)$ \\
Procornitermes araujoi & 6.63 & 8.26 \\
& $(0.76)$ & $(0.40)$ \\
Grigiotermes metoecus & 6.27 & - \\
& $(0.95)$ & \\
Armitermes euamignathus & 3.48 & 4.19 \\
& $(0.15)$ & $(0.52)$ \\
Cortaritermes silvestri & 3.23 & 2.08 \\
& $(0.12)$ & $(0.20)$ \\
Nasutitermes sp. & $3.46 \mathrm{c}$ & 1.56 \\
& $(1.06)$ & $(0.42)$ \\
& $2.52 \mathrm{c}$ & $1.31 \mathrm{~b}$ \\
& $(0.55)$ & $(0.09)$ \\
& & \\
\hline
\end{tabular}

a Equal number of all three morphs weighed.

b Only major soldiers weighed.

c Mixture of two worker types weighed. 


\section{Morphology of Soldiers}

The positions of measurements taken on soldier heads are indicated in Figure 2 (adapted from Coles 1980). Total body length was measured from tip of mandible or nasus, whichever extended further, to the end of the abdomen. The figures presented in Table 2 are the averages of 15 individual soldiers and are ordered from greatest to least mandible length. As can be seen, these five morphological measurements are, on the whole, positively correlated with each other, with total body length and with weight (Table 1). The major exception is Orthognathotermes, which has mandibles and a nasus of a different shape than the other species.

\section{Worker-Soldier Ratios}

Worker-soldier ratios were calculated by counting all of the workers and soldiers in a piece of termite mound. The piece was rapidly removed from the surrounding mound so as to prevent a change in the normal worker-soldier ratio. For all species except $P$. araujoi, A. euamignathus, $S$. dirus and $C$. silvestri, five pieces of mound from at least three different mounds were counted. The result obtained from a piece of mound was not used if the piece contained less than 600 individuals. Because of the large variation obtained in the first five counts for $P$. araujoi, an additional three pieces were counted. The fifth count used for $A$. euamignathus was an average of 45 samples and was taken from Domingos (1980). Only four counts were taken for $C$. silvestri.

The large diffuse mounds inhabited by $S$. dirus and the rapid retreat of soldiers and workers made it impossible to obtain workersoldier ratios from populations within the mound for this species. Instead, the value presented in Table 3 is an average of counts made on eleven foraging parties. The method used (Coles 1980) was to plug the exit at least one hour after foraging had begun. After spraying with pyrethrin aerosol insecticide all soldiers and workers were collected and counted. Table 3 presents the data on workersoldier ratios ordered from greatest to least percent soldiers.

Those termite species with soldiers having chemical-based defensive systems have fewer workers per soldier than the other termite species. In fact, for these species, Velocitermes, Nasutitermes and Cortaritermes, there is little variation between species in this worker-soldier ratio. Similarly, Cornitermes and Procornitermes, 

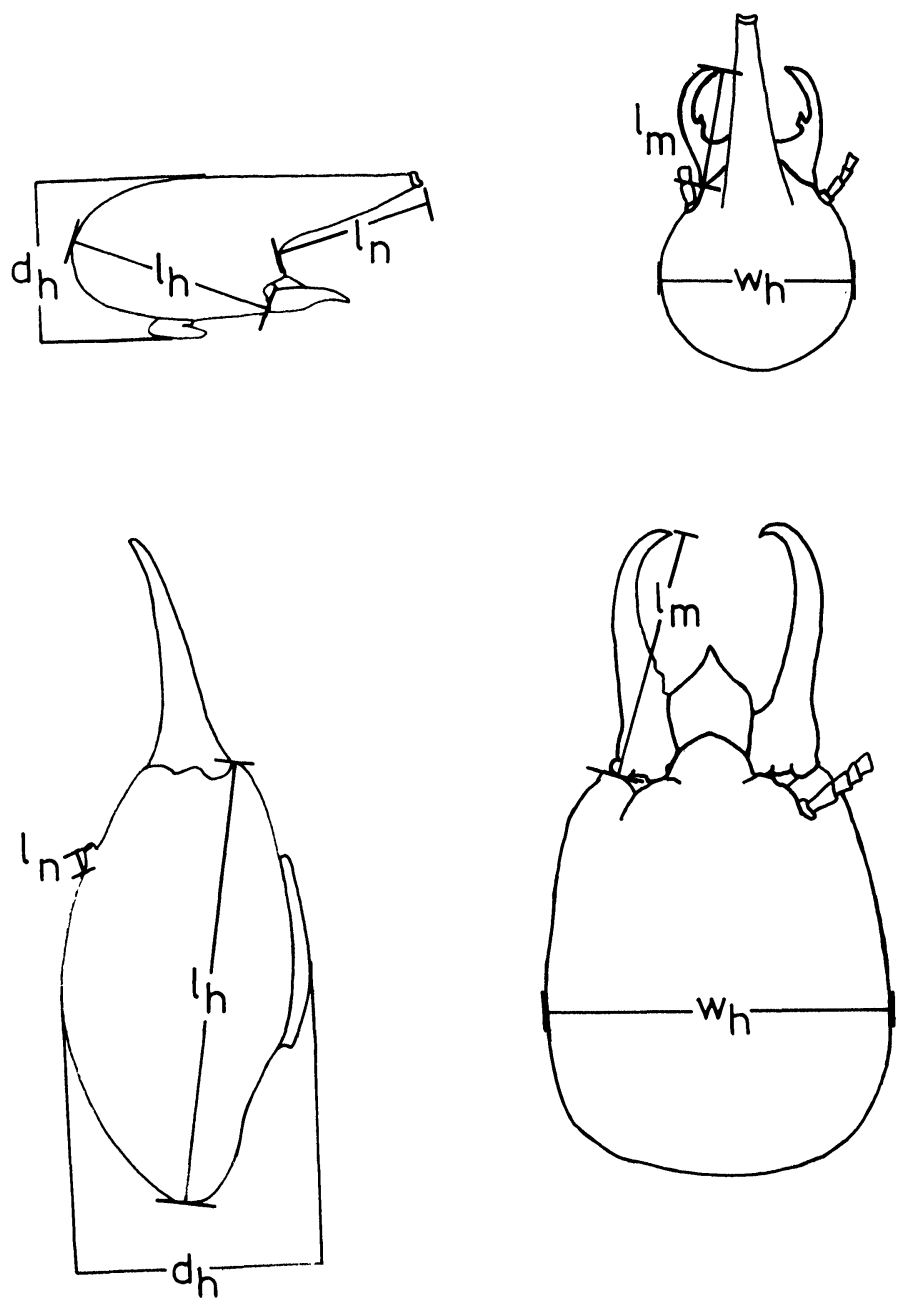

Figure 2. Positions of morphological measurements of soldier heads: $1 \mathrm{~h}=\mathrm{Lat}-$ eral head length; $1 \mathrm{n}=$ nasus length; $1 \mathrm{~m}=$ mandible length; $\mathrm{Wh}=$ maximum head width; $\mathrm{dh}=$ head depth including postmentum. 
Table 2. Morphological measurements of soldiers (measurements expressed in millimeters; mean with standard deviation in parenthesis).

\begin{tabular}{|c|c|c|c|c|c|c|}
\hline Species & $\begin{array}{l}\text { Mandible } \\
\text { Length }\end{array}$ & $\begin{array}{l}\text { Nasus } \\
\text { Length }\end{array}$ & $\begin{array}{c}\text { Lateral } \\
\text { Length } \\
\text { of } \\
\text { Head }\end{array}$ & $\begin{array}{c}\text { Maximum } \\
\text { Head } \\
\text { Width }\end{array}$ & $\begin{array}{l}\text { Head } \\
\text { Depth }\end{array}$ & $\begin{array}{c}\text { Total } \\
\text { Body } \\
\text { Length }\end{array}$ \\
\hline $\begin{array}{l}\text { Orthognathotermes } \\
\text { gibberorum }\end{array}$ & $\begin{array}{c}2.96 \\
(0.11)\end{array}$ & $\frac{0}{-}$ & $\begin{array}{c}3.06 \\
(0.08)\end{array}$ & $\begin{array}{c}2.09 \\
(0.06)\end{array}$ & $\begin{array}{c}1.83 \\
(0.05)\end{array}$ & $\begin{array}{c}9.25 \\
(0.40)\end{array}$ \\
\hline $\begin{array}{l}\text { Syntermes } \\
\text { dirus }\end{array}$ & $\begin{array}{c}2.45 \\
(0.11)\end{array}$ & $\begin{array}{c}0.16 \\
(0.02)\end{array}$ & $\begin{array}{c}5.20 \\
(0.19)\end{array}$ & $\begin{array}{c}5.15 \\
(0.15)\end{array}$ & $\begin{array}{c}3.17 \\
(0.14)\end{array}$ & $\begin{array}{l}15.57 \\
(0.65)\end{array}$ \\
\hline $\begin{array}{l}\text { Cornitermes } \\
\text { cumulans }\end{array}$ & $\begin{array}{l}1.36 \\
(0.78)\end{array}$ & $\begin{array}{c}0.36 \\
(0.03)\end{array}$ & $\begin{array}{c}3.90 \\
(0.11)\end{array}$ & $\begin{array}{c}2.67 \\
(0.09)\end{array}$ & $\begin{array}{l}1.95 \\
(0.07)\end{array}$ & $\begin{array}{c}9.55 \\
(0.42)\end{array}$ \\
\hline $\begin{array}{l}\text { Procornitermes } \\
\text { araujoi }\end{array}$ & $\begin{array}{l}1.14 \\
(0.05)\end{array}$ & $\begin{array}{c}0.45 \\
(0.03)\end{array}$ & $\begin{array}{c}2.46 \\
(0.03)\end{array}$ & $\begin{array}{c}1.98 \\
(0.04)\end{array}$ & $\begin{array}{c}1.57 \\
(0.05)\end{array}$ & $\begin{array}{c}7.47 \\
(0.21)\end{array}$ \\
\hline $\begin{array}{l}\text { Armitermes } \\
\text { euamignathus }\end{array}$ & $\begin{array}{c}0.58 \\
(0.02)\end{array}$ & $\begin{array}{c}0.91 \\
(0.05)\end{array}$ & $\begin{array}{c}2.05 \\
(0.05)\end{array}$ & $\begin{array}{c}1.10 \\
(0.04)\end{array}$ & $\begin{array}{c}1.04 \\
(0.05)\end{array}$ & $\begin{array}{l}5.35 \\
(0.20)\end{array}$ \\
\hline $\begin{array}{l}\text { Nasutitermes } \\
\text { sp. }\end{array}$ & $\begin{array}{c}0.17 \\
(0.03)\end{array}$ & $\begin{array}{c}0.63 \\
(0.02)\end{array}$ & $\begin{array}{c}1.65 \\
(0.64)\end{array}$ & $\begin{array}{c}1.05 \\
(0.35)\end{array}$ & $\begin{array}{c}0.82 \\
(0.34)\end{array}$ & $\begin{array}{c}4.32 \\
(0.14)\end{array}$ \\
\hline $\begin{array}{l}\text { Velocitermes } \\
\text { paucipilis }\end{array}$ & $\begin{array}{c}0.15 \\
(0.18)\end{array}$ & $\begin{array}{c}0.80 \\
(0.03)\end{array}$ & $\begin{array}{l}1.65 \\
(0.64)\end{array}$ & $\begin{array}{c}1.05 \\
(0.35)\end{array}$ & $\begin{array}{c}0.82 \\
(0.34)\end{array}$ & $\begin{array}{c}4.32 \\
(0.14)\end{array}$ \\
\hline $\begin{array}{l}\text { Cortaritermes } \\
\text { silvestri }\end{array}$ & $\begin{array}{c}0.15 \\
(0.02)\end{array}$ & $\begin{array}{c}0.61 \\
(0.03)\end{array}$ & $\begin{array}{c}1.64 \\
(0.06)\end{array}$ & $\begin{array}{l}1.08 \\
(0.06)\end{array}$ & $\begin{array}{c}0.80 \\
(0.06)\end{array}$ & $\begin{array}{c}3.95 \\
(0.25)\end{array}$ \\
\hline
\end{tabular}

Note: Grigiotermes is excluded for it has no soldiers.

two similar species have very similar workers-soldier ratios. Armitermes occupies an intermediate position while Orthognathotermes has a large number of workers per soldier.

\section{The Mounds}

\section{A. Mound size and form}

Table 4 presents data on mean heights, widths and lengths of ten mounds for each of the nine species of termites. Figure 3 (a-r) consists of two photographs of each species mound, one of an entire mound and the other of a mound in transverse cross-section. As can be seen from the data and the photographs, the shapes of these mounds range roughly from an inverted cone (Cornitermes) to a low dome (Orthognathotermes). 
Table 3. Proportion of workers in nests (mean with standard deviation in parentheses).

\begin{tabular}{lcc}
\hline Species & $\begin{array}{c}\text { Worker- } \\
\text { Soldier }\end{array}$ & $\begin{array}{c}\% \\
\text { Soldiers }\end{array}$ \\
\hline Velocitermes paucipilis & 4.00 & 25.80 \\
Nasutitermes sp. & $(0.72)$ & $(4.23)$ \\
& 4.06 & 25.50 \\
Cortaritermes silvestri & $(0.83)$ & $(5.56)$ \\
& 5.12 & 21.20 \\
Syntermes dirus* & $(1.64)$ & $(6.90)$ \\
Armitermes euamignathus & 9.66 & 11.10 \\
& $(2.72)$ & $(3.02)$ \\
Procornitermes araujoi & 13.82 & 7.68 \\
& $(3.79)$ & $(2.57)$ \\
Cornitermes cumulans & 30.12 & 5.10 \\
& $(18.30)$ & $(3.76)$ \\
Orthognathotermes gibberorum & 30.23 & 3.48 \\
& $(7.61)$ & $(3.14)$ \\
& & 1.30 \\
& $(18.18)$ & $(0.32)$ \\
\hline
\end{tabular}

*Figures derived from foraging parties. See text, Grigiotermes excluded as it has no soldiers.

The nature and form of individual mounds vary greatly and the characteristics listed below are generalized descriptions of mounds found in the Distrito Federal and Emas Park.

Cornitermes cumulans (Fig. $3 \mathrm{a}, \mathrm{b}$ ): The mound has a very hard outer shell of soil surrounding a soft inner core of carton (fecal material, communited plant material and bits of soil) which often extends below ground as much as $40 \mathrm{cms}$. The galleries are large and unlined.

Nasutitermes sp. (Fig. $3 \mathrm{c}, \mathrm{d}$ ): The mound is domed with the outer several centimeters softer than the inner core (as in arboreal Nasutitermes and Constrictotermes) and often extends $25 \mathrm{cms}$ underground. The internal structure consists of thin-walled, convoluted, 
Table 4. Dimensions of the epigeal portion of termite mounds (measurements expressed in centimeters; mean with standard deviation in parentheses).

\begin{tabular}{lccc}
\hline \multicolumn{1}{c}{ Species } & Height & Length & Width \\
\hline Cornitermes cumulans & 91.6 & 92.8 & 79.5 \\
& $(16.7)$ & $(17.1)$ & $(14.5)$ \\
Nasutitermes sp. & 78.1 & 100.1 & 85.9 \\
& $(14.3)$ & $(18.2)$ & $(16.4)$ \\
Syntermes dirus & 51.7 & 173.0 & 150.7 \\
& $(19.4)$ & $(26.5)$ & $(20.5)$ \\
Velocitermes paucipilis & 31.2 & 27.3 & 22.6 \\
& $(4.5)$ & $(7.0)$ & $(5.8)$ \\
Grigiotermes metoecus & 2.96 & 60.2 & 47.2 \\
& $(4.5)$ & $(7.9)$ & $(7.2)$ \\
Procornitermes araujoi & 28.8 & 69.5 & 60.0 \\
& $(12.0)$ & $(33.9)$ & $(34.4)$ \\
Armitermes euamignathus & 26.7 & 59.5 & 52.8 \\
& $(5.1)$ & $(8.8)$ & $(8.1)$ \\
Cortartiermes silvestri & 15.8 & 24.8 & 20.5 \\
& $(4.7)$ & $(3.2)$ & $(2.6)$ \\
Orthognathotermes gibberorum & 15.0 & 35.9 & 40.4 \\
& $(3.0)$ & $(11.3)$ & $(13.6)$ \\
\hline
\end{tabular}

irregular galleries with a mottled black and soil-colored lining of fecal origin.

Syntermes dirus (Fig. 3 e,f): This species builds low-domed termitaria, the major parts of which are below ground level (often to depth of $1.5 \mathrm{~m}$.). The galleries are large and diffuse, often containing grass stores and are lined with regurgitated soil in which individual pellets are clearly visible.

Velocitermes paucipilis (Fig. $4 \mathrm{~g}, \mathrm{~h}$ ): The mounds are pyramidal, very soft, crumbly and are generally built around a grass tussock. They often extend several centimeters underground in a series of very diffuse galleries which are lined with a discontinuous layer of black material of fecal origin. Large amounts of cut plant material are found inside the mound. 

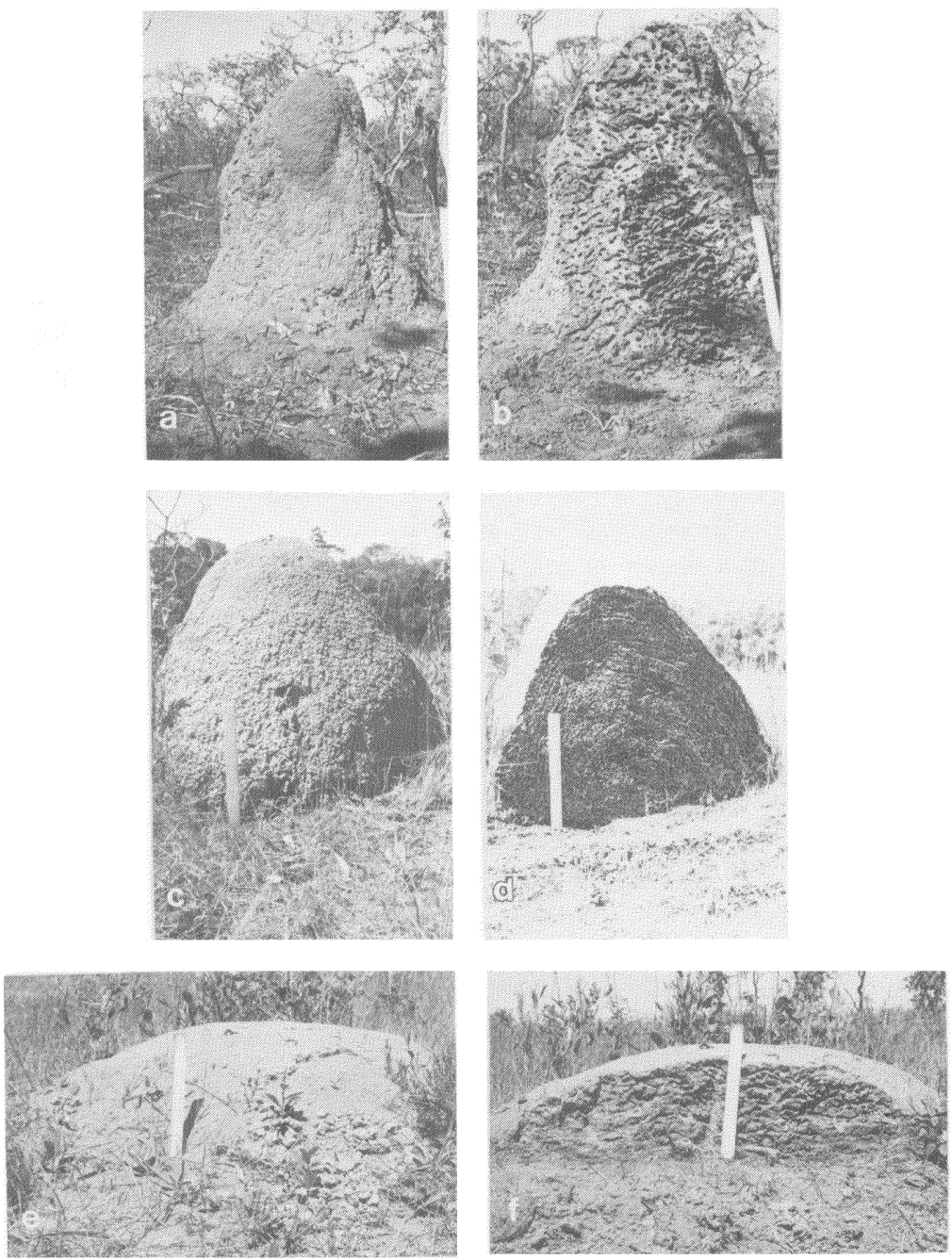

Figure 3. Mounds of the termite species studied; external view and longitudinal section: a and b, Cornitermes cumulans; $\mathrm{c}$ and d, Nasutitermes sp.; e and f, Syntermes dirus. 
Grigiotermes metoecus (Fig. 4 i,j): These medium-sized domed mounds are often occupied by other species of termites and ants. The galleries are distinguished by smooth, shiny soil-colored floors and by small pieces of stone incorporated into the 'ceilings.' Individual deposits of fecal material used in construction are visible on the mound surface.

Procornitermes araujoi (Fig. 4 k,l): These medium-sized, rounded mounds are often characterized by a thin layer of loose soil covering the outer shell. These mounds are quite brittle and homogenous and have galleries with a mottled lining of black soil and colored particles, probably of fecal origin. They rarely extend below ground.

Armitermes euamignathus (Fig. $5 \mathrm{~m}, \mathrm{n}$ ): This species builds very characteristic slightly domed mounds. The walls are very hard but the mound itself is only loosely held to the substratum with a cavity frequently occurring between it and the soil. The internal structure consists of large irregular chambers connected by very small galleries. During the alate flight season mounds of this species are characterized by earthen turrets several centimeters high built on the outer surface and serving as 'launching platforms' for alates.

Cortaritermes silvestri (Fig. 5 o,p): This species builds soft, low rounded mounds with large irregular galleries. The mounds are frequently built around grass tussocks and extend several centimeters underground as in Velocitermes.

Orthognathotermes gibberorum (Fig. 5 q,r): The low mounds built by this species are covered with loose soil and bound together by living grass stems. The galleries are regular and homogenous throughout. The mound frequently extends several centimeters underground but can be separated easily from surrounding soil when pried up.

\section{B. Mound hardness and nest material}

The 'hardness' of a mound was measured using a soil penetrometer which measures the force necessary to push a metal cone into the soil. The resistance to penetration is obtained by dividing the load of penetration (force applied) by the area at the base of the cone, which was $637.939 \mathrm{~mm}^{3}$. The resistance to penetration was taken as a measure of hardness of the mound surface.

A termite mound is not a solid structure but consists of a complex system of galleries and chambers. The outer wall is often thick enough for penetration of the whole cone. However, at times, the 

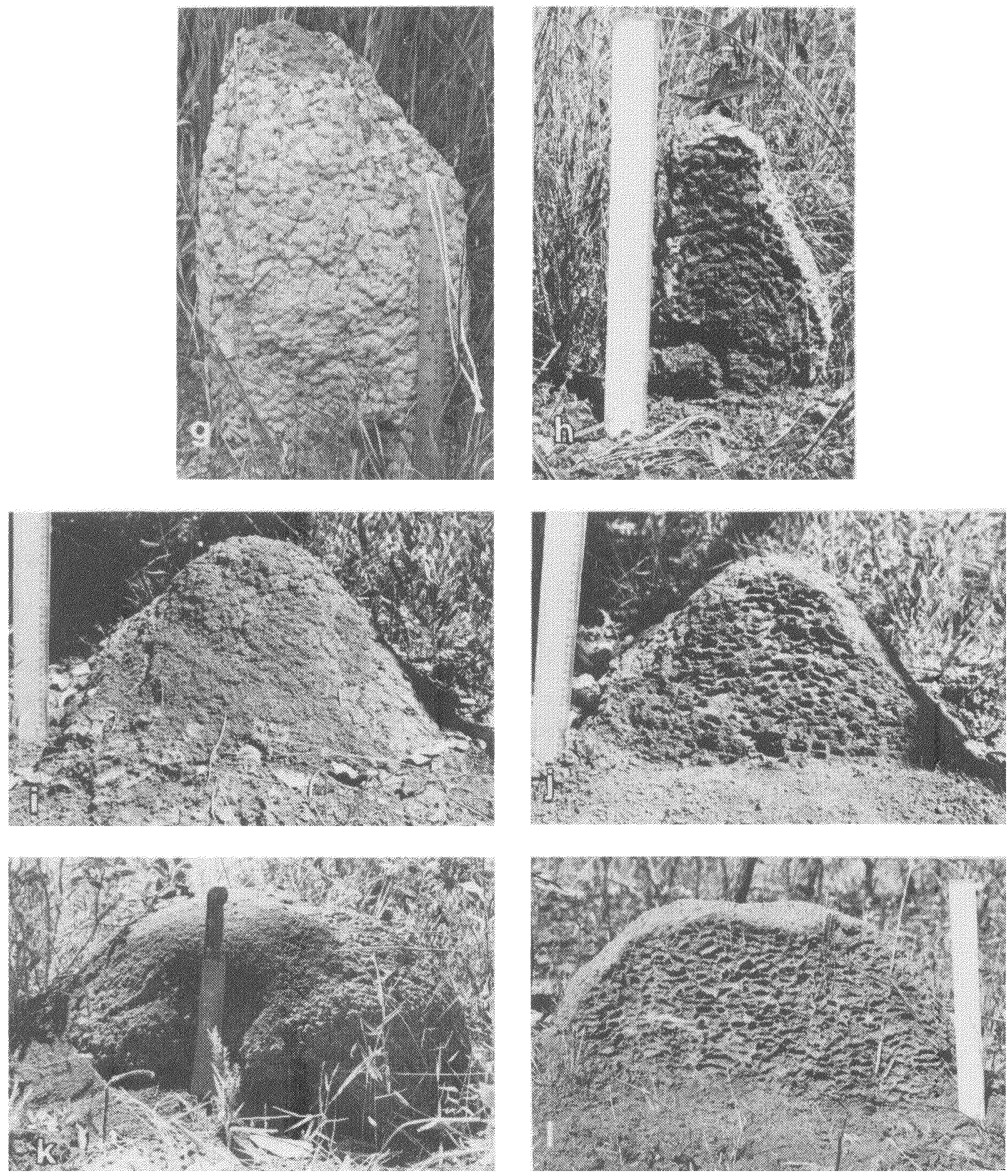

Figure 4. Mounds of the termite species studied; external view and longitudinal section: $\mathrm{g}$ and h, Velocitermes paucipilis; i and j, Grigiotermes metoecus; $\mathrm{k}$ and 1, Procornitermes araujoi.

cone pushed into a gallery and a low reading was obtained. In order to obtain a representative figure for the whole mound ten measurements were taken, each from different positions, e.g. base, middle, top.

The hardness of any mound varies considerably throughout the year with the amount of rainfall. To reduce these variations all the 

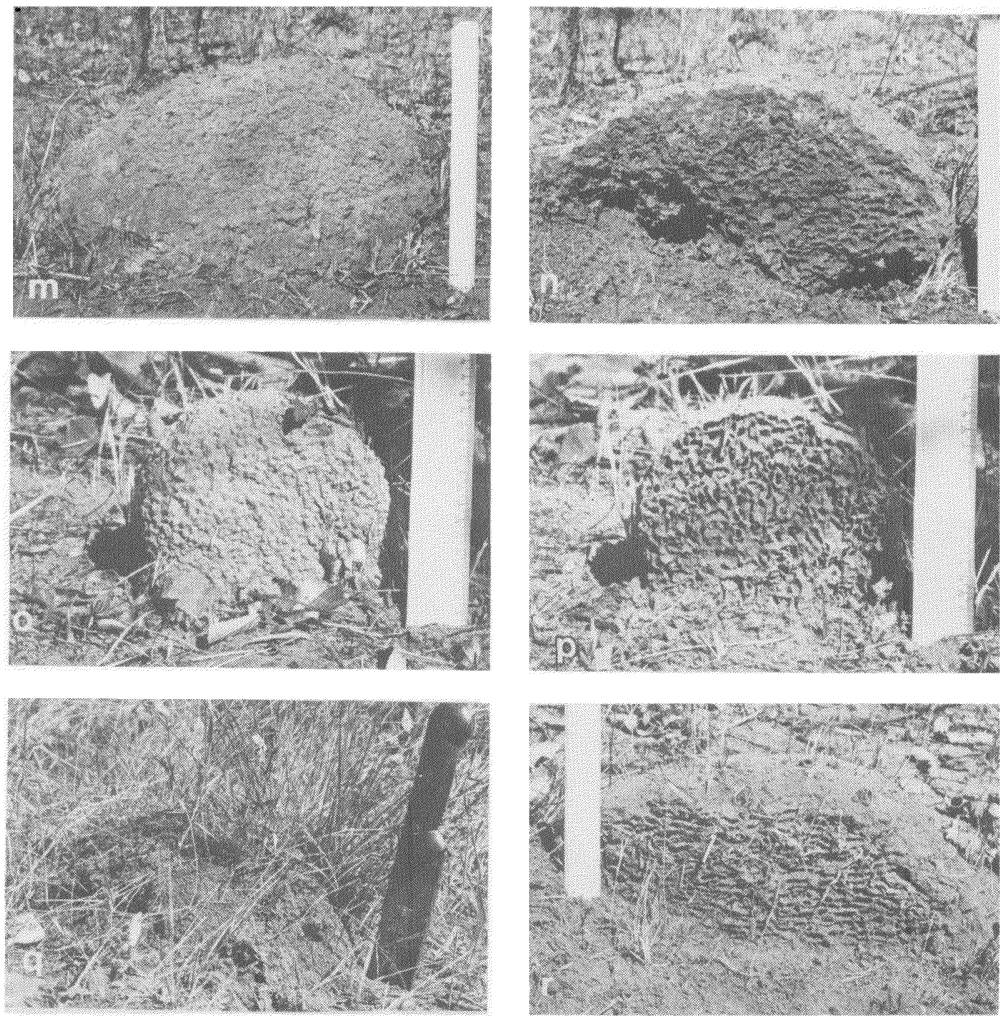

Figure 5. Mounds of the termites species studied; external view and longitudinal section: m and n, Armitermes euamignathus; o and p, Cortaritermes silvestri; $\mathrm{q}$ and r, Orthognathotermes gibberorum.

measurements were made in one month (April) at the end of the rainy season. Some variation in hardness occurs from day-to-day and so on any one day of recording, one mound from each of the eight species was examined. Ten mounds from each species were examined and ten measurements were made from each mound. Care was taken to select approximately the same size of mound for the ten mounds of any one species.

The mean values for the hardness of termite mounds in each species are shown in Table 5. As the range is large (15.24-0.11 Newtons $\left./ \mathrm{mm}^{3}\right)$ the data were transformed $(\sqrt{\mathrm{x}})$ and the differences 
Table 5. "Hardness" of outer mound and materials used in mound construction (In column 1, any two means not followed by the same letter are significantly different at $p=0.05$. In columns 3 through $6,++=$ usually used; $+=$ occasionally used).

\begin{tabular}{|c|c|c|c|c|c|c|}
\hline \multirow[b]{2}{*}{ Species } & \multicolumn{2}{|c|}{$\begin{array}{c}\text { Resistance to } \\
\text { Penetration (Newtons } \mathrm{mm}^{3} \text { ) }\end{array}$} & \multicolumn{4}{|c|}{ Nest Construction Material } \\
\hline & $\begin{array}{l}\text { Termite } \\
\text { Mound }\end{array}$ & $\begin{array}{l}\text { Soil at } \\
\text { Base }\end{array}$ & Soil & $\begin{array}{l}\text { Regurgitated } \\
\text { Soil }\end{array}$ & $\begin{array}{c}\text { Fecal } \\
\text { Material }\end{array}$ & Saliva \\
\hline $\begin{array}{l}\text { Velocitermes } \\
\text { paucipilis }\end{array}$ & $\begin{array}{r}0.11 \mathrm{a} \\
(0.05)\end{array}$ & $\begin{array}{c}0.48 \\
(0.16)\end{array}$ & ++ & ++ & & \\
\hline $\begin{array}{l}\text { Nasutitermes } \\
\text { sp. }\end{array}$ & $\begin{array}{l}0.25 \mathrm{~b} \\
(0.05)\end{array}$ & $\begin{array}{c}0.42 \\
(0.15)\end{array}$ & & ++ & ++ & ++ \\
\hline $\begin{array}{l}\text { Cortaritermes } \\
\text { silvestri }\end{array}$ & $\begin{array}{l}0.25 b \\
(0.04)\end{array}$ & $\begin{array}{c}0.44 \\
(0.18)\end{array}$ & ++ & & ++ & \\
\hline $\begin{array}{l}\text { Procornitermes } \\
\text { araujoi }\end{array}$ & $\begin{array}{l}0.36 \mathrm{~b} \\
(0.11)\end{array}$ & $\begin{array}{c}0.42 \\
(0.14)\end{array}$ & ++ & ++ & ++ & ++ \\
\hline $\begin{array}{l}\text { Orthognathotermes } \\
\text { gibberorum* }\end{array}$ & $\begin{array}{c}0.48 \\
(0.15)\end{array}$ & $\begin{array}{l}- \\
-\end{array}$ & ++ & & ++ & \\
\hline $\begin{array}{l}\text { Syntermes } \\
\text { dirus }\end{array}$ & $\begin{array}{r}0.57 \mathrm{c} \\
(0.13)\end{array}$ & $\begin{array}{c}0.42 \\
(0.14)\end{array}$ & + & ++ & & + \\
\hline $\begin{array}{l}\text { Grigiotermes } \\
\text { metoecus }\end{array}$ & $\begin{array}{l}1.25 \mathrm{~d} \\
(0.17)\end{array}$ & $\begin{array}{c}0.70 \\
(0.18)\end{array}$ & + & & ++ & \\
\hline $\begin{array}{l}\text { Armitermes } \\
\text { euamignathus }\end{array}$ & $\begin{array}{r}4.66 \mathrm{e} \\
(1.08)\end{array}$ & $\begin{array}{c}0.36 \\
(0.10)\end{array}$ & ++ & & + & \\
\hline $\begin{array}{l}\text { Cornitermes } \\
\text { cumulans }\end{array}$ & $\begin{array}{l}15.24 \mathrm{f} \\
(5.36)\end{array}$ & $\begin{array}{c}0.37 \\
(0.16)\end{array}$ & + & ++ & & ++ \\
\hline
\end{tabular}

*Determined for only 4 mounds so no statistics performed.

between these means tested for significance using Hartley's multiple range test. The ranking obtained from this analysis is shown in Table 5 with the mean values of the raw data. Velocitermes, Nasutitermes, Cortaritermes and Procornitermes had the softest nests while Cornitermes had the hardest nest, 140 times harder than the softest, Velocitermes.

The composition of material used to build mounds was determined by direct observation of workers. Observations were made on at least ten mounds per species, at different times of the day and year. The results are presented in Table 5. Four types of material 
were observed to have been used by termite workers in nest construction: soil, regurgitated soil, fecal material and saliva. In some cases, such as Procornitermes nests, all four were used. Soil and/or regurgitated soil were always the most common forms of building material.

C. Distribution and Abundance of Nests

Information on the distribution and abundance of termite mounds in each vegetation type was collected from a variety of sources and the results are presented in Table 6. Different sampling methods can produce different results, depending on the spatial distribution of the termite mounds, the size of area sampled and the number of areas sampled. It is often difficult to interpret figures on termitaria densities because investigators do not report whether all termitaria examined contained the mound-building species. Thus, the specific methods used to obtain each of the densities reported in Table 6 are detailed below.

Method a: (Coles 1980); method b (Domingos 1980); method c (Coles de Negret et al. in prep.).

Blocks of $50 \times 50$ meters were selected randomly in each of the four vegetation types studied in the Distrito Federal. As some of the termite species in the present study were occasionally found in mounds built by other species, in these methodologies, all the epigeal mounds in the area were completely excavated. The abundance of each species was thus expressed in numbers of nests per hectare. In order to exclude sites with only foraging termites, a "nest" was defined as a structure in which termite nymphs and larvae were present.

Method d: (Redford in prep.).

Twelve separate transects, each of 100 by 20 meters were marked out in the campo limpo vegetaton of Emas National Park, Goias. All the mounds built by Cornitermes cumulans in each transect were counted. The figure in Table 6 is the mean calculated from these twelve transects (standard deviation $=16.1$ ).

Method e: (Brandão in prep.).

Two blocks, 100 by 100 meters were marked out in separate areas of campo sujo and two others, of the same size, in areas of cerrado vegetation in the Distrito Federal. All the Syntermes dirus mounds present in each area were counted. As this species frequently constructs small soil domes, apparently for storing food, nests were 
Table 6. Distribution and densities of termite nests/mounds per hectare in four vegetation types (Letters correspond to different sampling methods-see text for details).

\begin{tabular}{|c|c|c|c|c|}
\hline Species & $\begin{array}{l}\text { Campo } \\
\text { Limpo }\end{array}$ & $\begin{array}{c}\text { Campo } \\
\text { Sujo }\end{array}$ & $\begin{array}{c}\text { Cerrado } \\
\text { Sensu Stricto }\end{array}$ & Cerradão \\
\hline $\begin{array}{l}\text { Grigiotermes } \\
\text { metoecus }\end{array}$ & $40 \mathrm{a}$ & $28 \mathrm{a}$ & $\begin{array}{r}24 \mathrm{a} \\
4 \mathrm{c}\end{array}$ & $48 \mathrm{a}$ \\
\hline $\begin{array}{l}\text { Armitermes } \\
\text { euamignathus }\end{array}$ & $\begin{array}{r}84 a \\
236 b\end{array}$ & $\begin{array}{c}112 \mathrm{a} \\
116 \mathrm{~b} \\
41 \mathrm{f}\end{array}$ & $\begin{array}{l}116 a \\
152 b \\
156 c\end{array}$ & $\begin{array}{l}124 \mathrm{a} \\
120 \mathrm{~b}\end{array}$ \\
\hline $\begin{array}{l}\text { Cornitermes } \\
\text { cumulans }\end{array}$ & $\begin{array}{r}0 \mathrm{a} \\
58 \mathrm{~d}\end{array}$ & $12 \mathrm{a}$ & $\begin{array}{r}32 \mathrm{a} \\
0 \mathrm{c}\end{array}$ & $0 \mathrm{a}$ \\
\hline $\begin{array}{l}\text { Cortaritermes } \\
\text { silvestri }\end{array}$ & $40 \mathrm{a}$ & $12 \mathrm{a}$ & $4 \mathrm{a}$ & $0 \mathrm{a}$ \\
\hline $\begin{array}{l}\text { Nasutitermes } \\
\text { sp. }\end{array}$ & $48 \mathrm{a}$ & $32 a$ & $\begin{array}{r}0 \mathrm{a} \\
16 \mathrm{c}\end{array}$ & $0 \mathrm{a}$ \\
\hline $\begin{array}{l}\text { Procornitermes } \\
\text { araujoi }\end{array}$ & $4 a$ & $12 \mathrm{a}$ & $\begin{array}{l}52 \mathrm{a} \\
12 \mathrm{c}\end{array}$ & $4 a$ \\
\hline Syntermes dirus & $4 a$ & $\begin{array}{l}20 \mathrm{a} \\
33 \mathrm{e} \\
54 \mathrm{e}\end{array}$ & $\begin{array}{l}0 \mathrm{a} \\
0 \mathrm{e} \\
8 \mathrm{e}\end{array}$ & $0 \mathrm{a}$ \\
\hline $\begin{array}{l}\text { Velocitermes } \\
\text { paucipilis }\end{array}$ & $40 \mathrm{a}$ & $\begin{array}{r}96 \mathrm{a} \\
101 \mathrm{f} \\
27 \mathrm{~g}\end{array}$ & $\begin{array}{l}32 \mathrm{a} \\
24 \mathrm{c}\end{array}$ & $0 \mathrm{a}$ \\
\hline $\begin{array}{l}\text { Orthognathotermes } \\
\text { gibberorum }\end{array}$ & $12 a$ & $0 \mathrm{a}$ & $16 \mathrm{a}$ & $4 a$ \\
\hline
\end{tabular}

again defined as structures in which termite nymphs and larvae were present.

Methodf: (Curado et al. in prep.).

All the mounds built by Armitermes euamignathus and Velocitermes paucipilis in an area of campo sujo (100 by 100 meters) in the Distrito Federal were sampled and counted.

Method g: (internal report, University of Brasilia).

Mounds of Velocitermes paucipilis present in a transect 230 by 10 meters extending from campo limpo to campo sujo in the Distrito Federal were counted. 


\section{Feeding Habits and Foraging Behavior}

Feeding habits were deduced from field observations, examination of worker mandibles and gut contents, information in the literature and in some cases, from laboratory food preference experiments. Results are summarized in Table 7. Details of foraging behavior, methods of investigation and food sources are given below.

\section{Grigiotermes metoecus}

Field observations and examinations of worker mandibles and gut contents indicate that this species is entirely geophagous. It excavates subterranean galleries in the soil surrounding its mound and is also frequently found in old, disused termite workings, presumably rich in organic material.

\section{Armitermes euamignathus}

In the cerrado and cerradão vegetations foraging workers can be found under the bark of living trees and sound, dead trees. However, this species also occurs with equal frequency in campo limpo where few or no woody shrubs exist. Field observations on the foraging behavior of 100 colonies of this species show that in the absence of woody vegetation they can exploit the root systems of grasses (Domingos 1980). Laboratory food preference experiments carried out by the same author on five colonies of A. euamignathus indicates that when presented with a range of food sources, all colonies selected wood in preference to bark, litter and grass roots. Further field observations confirmed that this species selects dead, sound wood in preference to live and to dead, decomposed wood. The workers forage diurnally and reach the food source via subterranean galleries. On average, mounds are 0.4 and 0.3 meters from their food sources in cerradao and cerradão respectively and 1.2 and 1.0 meters in campo sujo and campo limpo, respectively (Domingos op. cit.).

\section{Cornitermes cumulans}

Field observations on foraging parties indicate that workers of this species feed on living and dead grasses and herbs, which they reach through subterranean tunnels, occasionally foraging under a fine layer of soil-sheeting. Small pieces of grass are cut from standing grass tussocks and carried to the mound. Feeding in situ has been observed occasionally. Preliminary food preference experi- 
Table 7. Modal feeding habits $(++=$ commonly consumed; $+=$ occasionally consumed).

\begin{tabular}{|c|c|c|c|c|}
\hline \multirow[t]{2}{*}{ SPECIES } & \multicolumn{4}{|c|}{ FOOD SOURCE } \\
\hline & Humus & $\begin{array}{l}\text { Sound } \\
\text { Wood }\end{array}$ & $\begin{array}{c}\text { Decomposing } \\
\text { Wood }\end{array}$ & $\begin{array}{c}\text { Grass \& } \\
\text { Herbaceous } \\
\text { Litter }\end{array}$ \\
\hline $\begin{array}{l}\text { Grigiotermes } \\
\text { metoecus }\end{array}$ & ++ & & & \\
\hline $\begin{array}{l}\text { Armitermes } \\
\text { euamignathus }\end{array}$ & & ++ & & + \\
\hline $\begin{array}{l}\text { Cornitermes } \\
\text { cumulans }\end{array}$ & & & & ++ \\
\hline $\begin{array}{l}\text { Cortaritermes } \\
\text { silvestri }\end{array}$ & $+(?)$ & & & $+(?)$ \\
\hline Nasutitermes sp.n. & & + & + & ++ \\
\hline $\begin{array}{l}\text { Procornitermes } \\
\text { araujoi }\end{array}$ & & & & ++ \\
\hline S!ntermes dirus & & & & ++ \\
\hline $\begin{array}{l}\text { Velocitermes } \\
\text { paucipilis }\end{array}$ & & & & ++ \\
\hline $\begin{array}{l}\text { Orthognathotermes } \\
\text { gibberorum }\end{array}$ & $++(?)$ & & & \\
\hline
\end{tabular}

ments carried out on laboratory colonies showed that workers collect dead grass in greater amounts than live. When presented with only dead roots or dead grass blades, they fed more on the latter.

\section{Cortaritermes silvestri}

Field observations made in the Distrito Federal and information presented in Mathews (1977) indicate that this species feeds in grass tussocks among the roots and stems. It is not clear, however, whether it feeds on the organic residues in the soil or on the grass roots themselves.

\section{Nasutitermes sp.}

These termites have not been observed foraging in the open and rarely construct runways over the ground as do many other species in this genus. It is probable that they excavate underground tunnels to their food source, the exact nature of which is not known. Recent 
experiments on laboratory colonies have shown that this species can feed on a range of plant material including sound wood and both living and dead grass.

\section{Procornitermes araujoi}

Field observations have been made on above-ground foraging parties in the open and under soil sheeting. Workers cut and collect grass litter, generally at night, but occasionally on dull, humid days.

\section{Sintermes dirus}

This species forages above ground in the open, at night, and crepuscularly. Workers and soldiers leave the tunnels from small exit holes which are plugged with several millimeters of soil during inactive periods. These foraging holes may be on the mound or at distances of up to 20 meters from it. The above-ground foraging parties consist of major workers and soldiers. At the end of a particular trail the workers spread out over several centimeters and start cutting grass. Some climb up stands of vegetation and cut long pieces of grass which drop to the ground. Other workers cut these into smaller pieces and carry them to the nest. Consumption in situ has not been observed.

\section{Velocitermes paucipilis}

These termites feed on grass and surface litter which they collect at night in the open. The workers form trails to the food source where they spread out to cover a large area, cut small pieces of grass and leaves, and return with them to the nest. The workers are flanked at regular intervals by soldiers oriented with their raised heads pointing outwards.

\section{Orthognathotermes gibberorum}

Examination of worker mandibles and gut contents together with information from Mathews (1977) suggests that this species feeds on organic residues in the soil. Observations of foraging behavior have not been made.

Food sources were divided into four categories: humus, sound wood, decomposing wood, and grass and herbaceous litter. The few termites eating sound wood and the many eating grass and herbaceous litter probably reflect the fact that most of the vegetation types included in this study were open with few trees. Examination of the termite fauna within the gallery forests would reveal many 
more wood-eating species. The predominance of grass-eating termites is understandable because of the large biomass and rapid turnover of their food source.

Of the 54 species of termites in the cerrado vegetation of the Distrito Federal (excluding gallery forests) only nine moundbuilding species were examined in this study. Many of the other species do not build mounds and are found instead living within mounds built by one of these nine species. It is probable that many of these non-mound-building species will be found to be geophagous or humivorous, feeding in or near the mounds they inhabit.

\section{Discussion}

The cerado vegetation of the Distrito Federal, Brazil has a diverse termite fauna with at least 54 species present (excluding those found in gallery forest vegetation) (Coles 1980). Estimates of the termite density in savanna areas in other continents are much lower with only 19 species in the Sahel, Senegal, 19 in northern Guinea, Nigeria, 23 in southern Guinea, Nigeria and 36 in savannas of the Ivory Coast (Wood and Sands 1978).

A survey by Coles (1980) indicated that most cerrado species were present in all the physionomic vegetation types; however, in terms of abundance, certain species were more common in one particular type of vegetation. This is clearly illustrated by the data in Table 6 . Nests of Nasutitermes sp., Velocitermes paucipilis, Cortaritermes silvestri, Syntermes dirus and Cornitermes cumulans were all more abundant in the open vegetation types (campo limpo and campo sujo). Grigiotermes metoecus and Armitermes euamignathus were equally common in all types while Procornitermes araujoi was more common in woodland areas. Orthognathotermes gibberorum had an irregular distribution being less common in the cerrado sensu strictu of the Distrito Federal but more common in the campo limpo of Emas Park. These preferences for particular vegetation types can, to some extent, be related to the feeding habits of each species (Table 7); however, abundance of a species is also influenced by other species present. In some areas conditions were particularly favorable for one species, an example of which was found in Emas National Park where populations of Cornitermes cumulans were exceptionally high, with other species much less common.

The variation in abundance of a species in different regions can be 
accompanied by variations in mound form and size. Howse (1979) gives several different examples of termite species which build very different mounds in different regions. Macrotermes subhyalinus in western Uganda builds mounds with very thick walls and no openings but on the Serengeti Plains, where the soil is volcanic ash, the mounds are low with many pit-like openings. In the semi-arid regions of eastern Africa they are different again, being steepleshaped and constructed around a central chimney. Even though regional differences can exist, the characteristics of mounds investigated in this study showed a remarkable consistency throughout the cerrado region reinforcing observations by Emerson (1938).

In constructing a mound, galleries are excavated within the soil by the termites and particles are often transported from considerable depth and incorporated in the epigeal portion of the mound. This not only increases aeration of the soil but can also alter its chemical composition (Lee and Wood 1971). Soil used in building is reinforced with excreta and in some instances wood and other plant material.

Studies on the chemical composition of termite mounds in the cerrado have recently been started in Brasilia. Preliminary results indicate that both Velocitermes and Armitermes mounds have much higher concentrations of calcium, phosphorus, potassium and aluminum than the soil surrounding the mound (Curado et al. in prep.). However, an analysis of Table 5 shows that the materials used in mound building are not directly related to the hardness of the outer layer of the mound. Such factors as the way in which the material is deposited by the workers at the actual site of construction as well as the size and arrangement of galleries and the thickness of walls also contribute to the overall hardness of the mound.

The mounds are constructed entirely by the worker caste. This caste takes little active role in the defense of the mound, a role performed by the soldier caste. The proportion of these two castes varies with the species and is apparently finely regulated by pheromones produced by the queen and the soldiers (Lüscher 1961). Haverty (1977), in a comprehensive work, summarized the data available on the relative proportion of workers and soldiers in 112 species of termites. Unfortunately, many of these data, gathered by different investigators, are not strictly comparable because of differences in sampling techniques and types of groups sampled. The 
homogeneity in methodology used in calculating worker-soldier ratios in this study allows for precise comparison between species within the limits of accuracy of this method. The worker-soldier ratios were found to vary greatly between nests in some species (i.e., Procornitermes) and remain quite constant in others (i.e., Velocitermes).

The behavior of nasute soldiers, which respond to a break in the nest by rapidly recruiting to the break, can greatly alter the workersoldier ratio calculated. As an example of this, on one occasion the number of soldiers counted from a piece of Nasutitermes mound, which had been excised from the surrounding mound but left in place for 30 seconds, was almost half again the number of soldiers counted from a piece taken from the same mound but removed immediately following excision. Although comparison can be made between the nine species of termites it must be noted that these data were taken during one period of the year and present a static picture of the proportions of workers and soldiers in given nests. It seems probable that in the species examined, as in other species (Sands 1965), the worker-soldier ratio varies seasonally and possibly also with the age and size of the nest.

It is evident from the data that some species have proportionally many more soldiers than other species. Even though the proportion of soldiers in a colony varies, in all cases (when there is a soldier caste) the soldier caste is largely responsible for the defense of the colony and has morphological features which allow it to do this. The type of defense used by soldier termites tends to be based on chemicals, mechanical defense or a combination of both. The soldier type using a chemical-based defense has vestigial mandibles (Table 2), is lighter than its workers (Table 1), and produces potentially toxic and repellent secretions which are ejected from the tip of a long tube or nasus at the front of the head (Nutting et al. 1974, Eisner et al. 1976; Howse 1975; Prestwich 1979). Of the termites studied in this work, Velocitermes, Nasutitermes and Cortaritermes fall into this category. The soldier type using a mechanical-based defense rarely produces defensive secretions and has a large head, and strong, sharp mandibles. Orthognathotermes is the only species within those here studied that has no development of the nasus, relying solely on its mandibles for defense. Syntermes, Cornitermes and Procornitermes all have strong mandibles which can pierce human skin, drawing blood, together with a greatly reduced level of 
chemical defense (see 'nasus length' Table 2 as one indicator of the extent to which chemicals are used in defense). Armitermes stands in an intermediate position between the principally chemical and the principally mandibulate type soldiers, with a long nasus and mandibles which can pierce human skin but not draw blood. Grigiotermes is very interesting in that it has no soldiers; the workers however produce a large drop of liquid on either side of the abdomen when disturbed, which may serve a defensive purpose.

Termites are probably the dominant form of animal life in many areas of central Brazil, both in number of species and biomass. They play major roles in herbivory, decomposition, soil formation and alteration, and as an important source of food for other animals. Ants are probably the major predators of termites, but in central Brazil mammals are common and important predators as well. The aspects of termite biology reported in this study are all important in defense by termites against mammalian predators. The small size of termites, the type of soldier defense and the proportion of soldiers to workers are all factors influencing feeding by mammals once the termite mound has been opened. The shape, size and hardness of a mound influence the ways in which a mammalian predator can break into a nest while the distribution and abundance of nests are a measure of the spatial availability of termites as a food source. Lastly, the feeding habits of termites are important in determining when, and if, termites are available outside of the mound. Food preference tests with large and small mammalian predators and observation of wild giant anteaters (Redford in prep.) have shown that all of these aspects of termite biology interact in determining which species of termites are preferred as food and how available they actually are to mammalian predators.

\section{ACKNOWLEDGEMENTS}

Helen Coles de Negret would like to thank the Trustees of the Royal Society Leverhulme Scholarships and the Science Research Council-Shell Research CASE award for financing this research. The data form part of a Ph.D. thesis submitted to Southampton University in 1980 under the supervision of Dr. P. E. Howse.

Kent Redford would like to thank the National Geographic Society, the Museum of Comparative Zoology, the Organization of American States and Sigma XI for help in financing this research. 
Special thanks to the members of the Order of Saint Benedict and the Laboratory of Ecology, University of Brasilia. Both authors thank Barbara L. Thorne, Alan E. Mill, James F. A. Traniello and Bert Hölldobler for reading and criticizing the manuscript.

\section{Literature Cited}

Araujo, R. L.

1961. New genus and species of Brazilian termite. Revta. Bras. Biol. 21, 105-111.

1969. Notes on Dentispicotermes with description of a new species. (Isoptera, Termitinae). Revta. Bras. Biol. 29, 249-254.

1970. Termites of the Neotropical Region. In: Biology of Termites, Vol. II, (Ed. by K. Krishna and F. M. Weesner) pp. 527-571, Academic Press, N. Y.

1977. Catalogo dos Isoptera do Novo Mundo. Academia Brasileira de Ciencias. Rio de Janeiro, RJ.

BANDiRA, A. G.

1979. Ecologia de cupins (Insecta: Isoptera) da Amazonia central: efeitos do desmatamento sobre as populacoes. Acta amazonica 9, 481-499.

BRANDÃo, D. in prep.

Ecologia de duas especies simpatricas de Syntermes (Isoptera; Nasutitermitinae) no Distrito Federal do Brasil.

COLES, H. R.

1980. Defensive strategies in the ecology of Neotropical termites. Ph.D. thesis Southampton University. $243 \mathrm{pp}$.

Coles de Negret, H. R., Domingos, D. J. and Fontes, E. G. in prep.

Spatial distribution of termite mounds in the cerrado vegetation, Distrito Federal, Brazil.

Curado, W., Coles de Negret, H. R., Haridasan, M. in prep.

Composition of the nest material of two termite species and the soil of their bases.

Domingos, D. J.

1980. Biologia, densidade e distribuiçao espacial de duas espécies de Armitermes (Termitidae) em cinco formaçōes vegetais do cerrado. M.Sc. thesis Universidade de Brasilia. 22 pp.

Eisner, T., Kriston, I. ANd Aneshansley, D. J.

1976. Defensive behaviour of a termite Nasutitermes exitiosus. Behav. Ecol. Sociobiol. 1, 83-125.

EITEN, G.

1972. The cerrado vegetation of Brazil. Bot. Rev. 38, 201-341.

EMERSON, A. E.

1938. Termite nests. A study of the phylogeny of behaviour. Ecol. Monographs. 8, 247-284.

1952. The Neotropical genera Procornitermes and Cornitermes (Isoptera, Termitidae). Bull. Am. Mus. Nat. Hist. 99, 429-471. 
FONTES, L. R.

1979. Atlantitermes novo genero de cupim, com duas novas especies do Brasil. (Isoptera, Termitidae, Nasutitermitinae) Rev. Bras. Ent. 23, 219-227.

HAVERTY, M. I.

1977. The proportion of soldiers in termite colonies: a list and a bibliography. Sociobiology 2, 199-216.

HowsE, P. E.

1975. Chemical defenses of ants, termites and other insects: some outstanding questions. Proc. IUSSI. (Dijon), 23-29.

1979. The uniqueness of insect societies: aspects of defense and integration. In: Biology and Systematics of Colonial Organisms (Ed. by G. Larwood and B. R. Rosen), pp. 345-374. Academic Press, New York.

LeE, K. E. AND Wood, T. G.

1971. Termites and Soils. Academic Press, New York.

LÜSCHER, M.

1961. Social control of polymorphism in termites. In: Insect Polymorphism (Ed. by J. S. Kennedy), pp. 57-67. Roy. Entomol. Soc., London.

Mathews, A. G. A.

1977. Studies on termites from the Mato Grosso State, Brazil. Academia Brasileira de Ciências, Rio de Janeiro, RJ. 267 pp.

Nutting, W. L., Blum, M. A. and Fales, H. M.

1974. Behavior of the North American termite Tenuirostritermes tenuirostris with special reference to the soldier frontal gland secretion, its chemical composition and use in defense. Psyche, 81, 167-177.

Prestwich, G. D.

1979. Chemical defense by termite soldiers. J. Chem. Ecol. 5, 459-480.

SANDS, W. A.

1965. Mound population movements and fluctuations in Trinervitermes ebenerianus Sjostedt (Isoptera, Termitidae, Nasutermitinae). Insect. Soc. 12, 49-58.

Wood, T. G. AND SANDS, W. A.

1978. The role of termites in ecosystems. In: Production biology of ants and termites (Ed. by M. V. Brian), pp. 245-292. Cambridge University Press. 

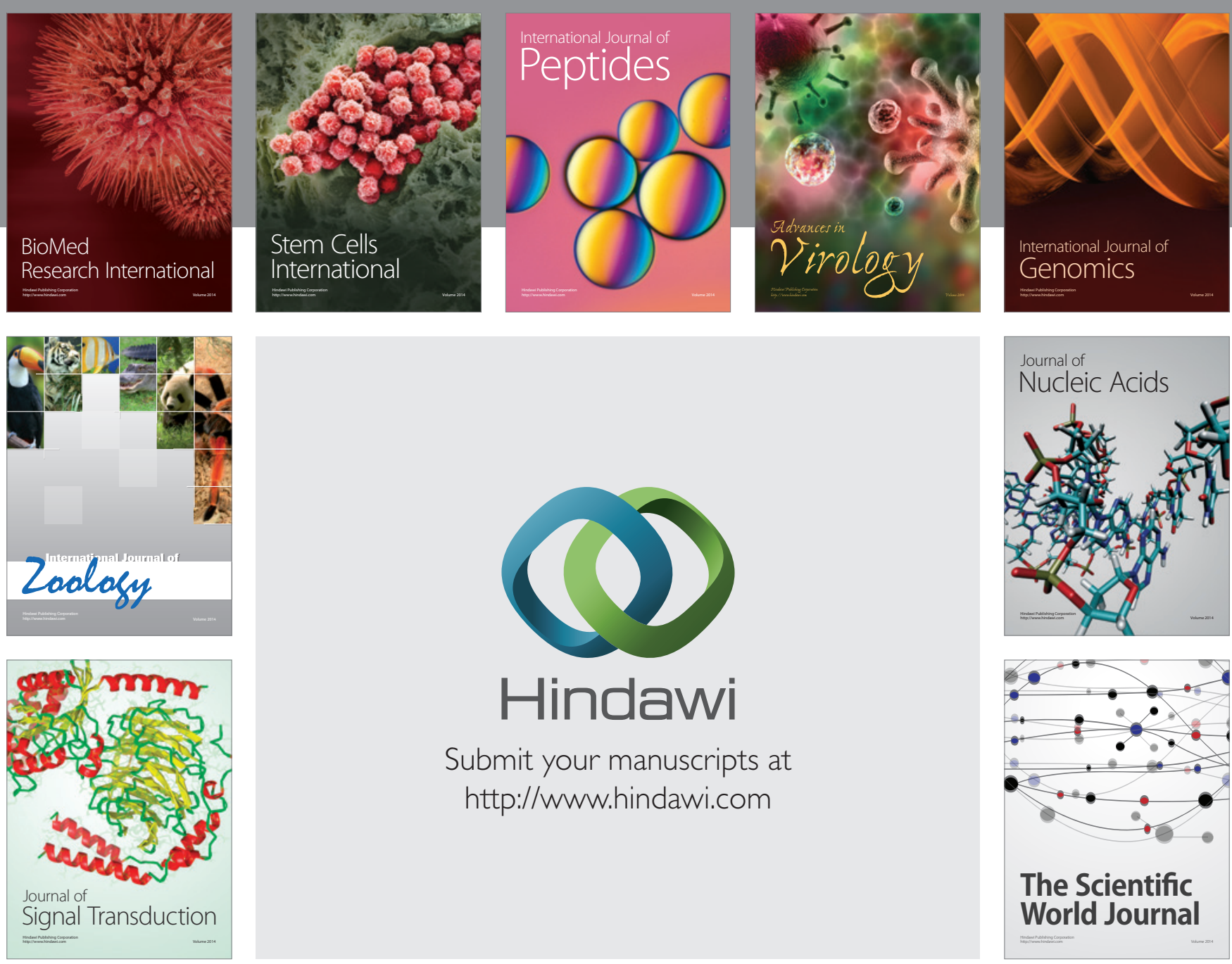

Submit your manuscripts at

http://www.hindawi.com
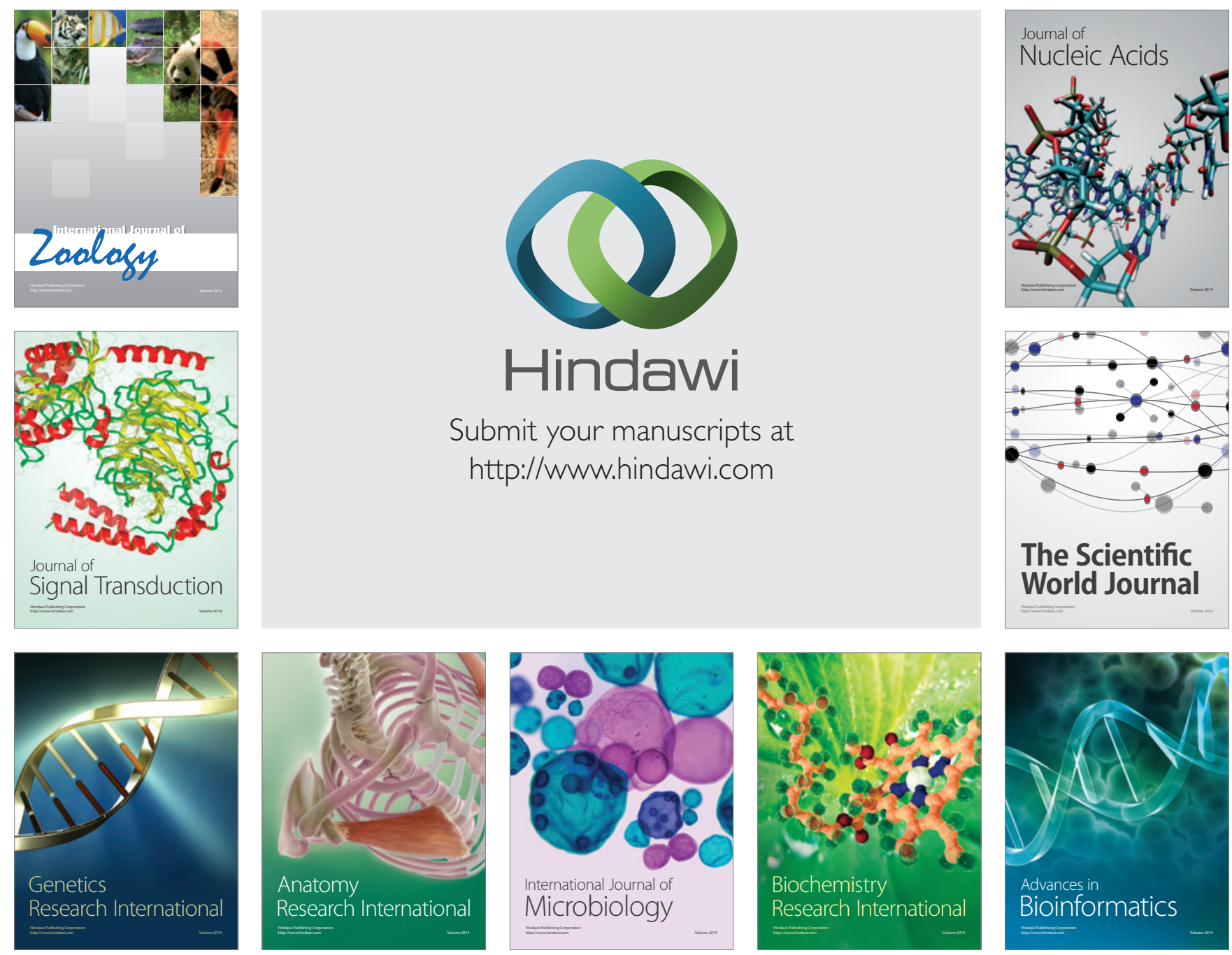

The Scientific World Journal
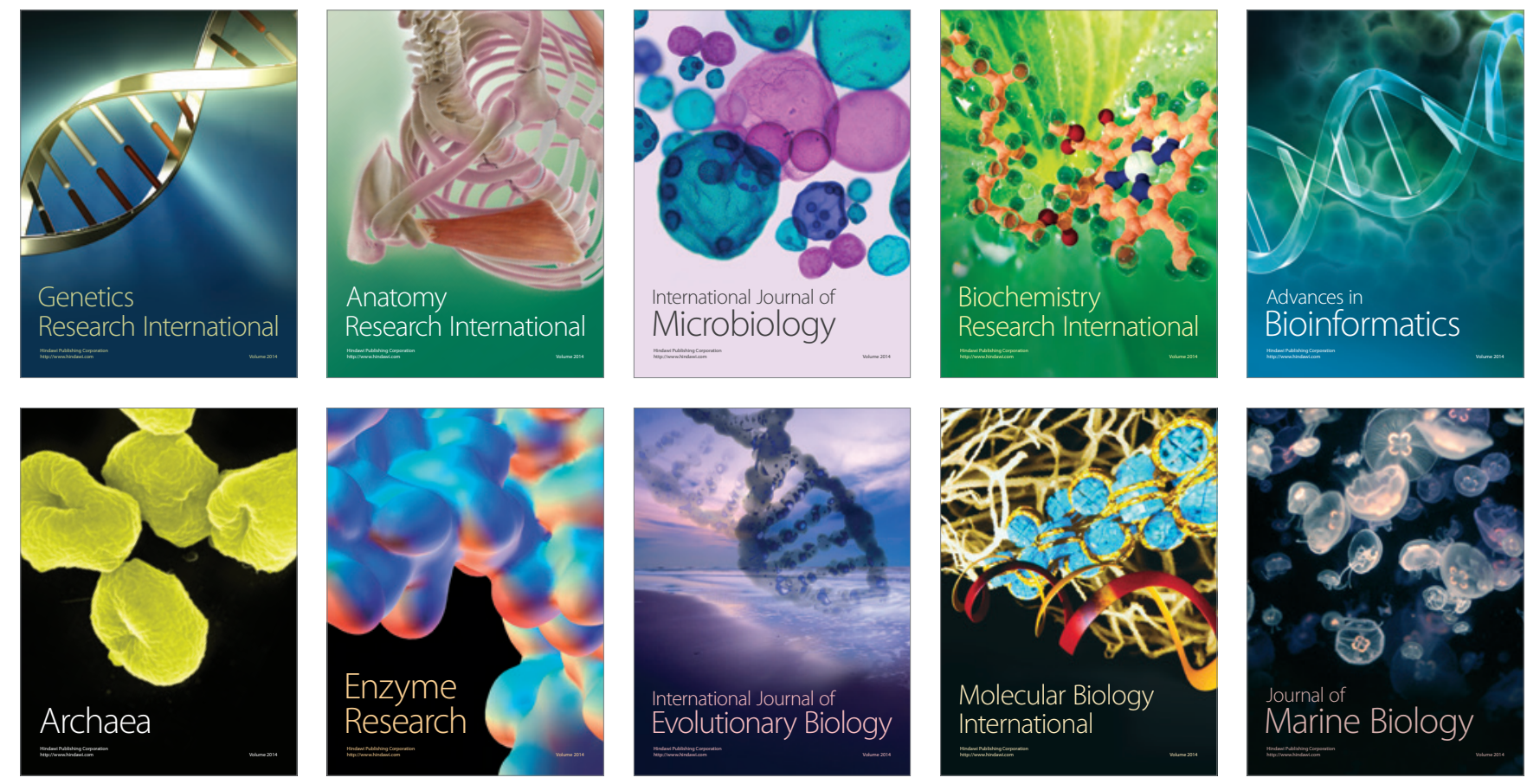